\section{Selection Against Pratylenchus vulnus Populations Attacking Prunus Rootstocks}

\author{
Jorge Pinochet ${ }^{1}$ and Carolina Fernández ${ }^{1}$ \\ Agromillora Catalana, S.A. El Rebato s/n, 08739 T.M. Subirats, Barcelona, \\ Spain
}

Cinta Calvet $^{2}$ and Adriana Hernández-Dorrego ${ }^{3}$

Departamento de Protección Vegetal, Institut de Recerca i Tecnologia Agroalimentàries, Ctra. de Cabrils s/n 08348, Cabrils, Barcelona, Spain

\section{Antonio Felipe ${ }^{4}$ \\ Departamento de Fruticultura, Servicio de Investigación Agraria, Apartado 727, 50080 Zaragoza, Spain}

Additional index words. genetic variability, host suitability, resistance, peach-almond hybrids, root-lesion nematode, stone fruits

\begin{abstract}
Twenty-nine commercial and experimental Prunus rootstocks, most with incorporated root-knot nematode [Meloidogyne javanica (Traub.) Chitwood] resistance, were evaluated against mixtures comprising nine populations of the root-lesion nematode Pratylenchus vulnus Allen and Jensen. Nearly all tested materials were susceptible. Five cultivars with high resistant levels were further challenged with seven $P$. vulnus populations individually. 'Redglow' (Prunus salicina Lindl. $x$ P. munsoniana Wight and Hedrick) was the only rootstock that showed broad resistance to all populations. The rootstocks 'Torinel' ( $P$. domestica L.), AC-595 (P. domestica X P. insititia L.), 'Marianna 4001' (P. cerasifera Ehr. $x$ P. munsoniana), and 'Felinem' [P. dulcis (Mill.) D. A. Webb $\times$ P. persica (L.) Batsch] showed resistance to one or a few $P$. vulnus populations. Several supposedly resistant sources proved to be susceptible. Tests of crosses made between parents of diverse genetic background with partial resistance to $P$. vulnus indicate that a descendant with potential $P$. vulnus resistance is difficult to obtain. Pathogenic diversity among $P$. vulnus populations appears to be high.
\end{abstract}

The root-lesion nematode Pratylenchus vulnus is regarded as economically important in stone fruit crops in warm Mediterranean environments. This species is widespread in Southern Europe (Lamberti, 1981; Scotto La Massese, 1989), California (McKenry, 1988), and the southeastern United States (Nyczepir and Becker, 1998) where it can play an important role in replant problems (Bertrand, 1989; García de Otazo, 1992; McElroy, 1972; Ricciardi et al., 1975). The extent of growth reduction caused by $P$. vulnus has been documented for almond $[P$. dulcis (Mill.) D.A. Webb], cherry (P. avium L.), peach [P. persica (L.) Batsch], and plum (P. domestica L.)

Received for publication 16Feb. 2000. Accepted for publication 15 May 2000. This research was supported by the Instituto Nacional de Investigaciones Agrarias (INIA), Grant No. SC97-055. We thank M. A. Moreno of the Estación Experimental Aula Dei, Consejo Superior de Investigaciones Científicas, Zaragoza, for providing plant material. The cost of publishing this paper was defrayed in part by the payment of page charges. Under postal regulations, this paper therefore must be hereby marked advertisement solely to indicate this fact.

${ }^{1}$ Nematologist. E-mail address: agropinochet@ ediho.es.

${ }^{2}$ Plant Pathologist.

${ }^{3}$ Graduate Assistant.

${ }^{4}$ Plant Breeder.
(Alcañiz et al., 1996; Ledbetter, 1994; Scotto La Massese, 1975).

A significant effort in incorporating host plant resistance against this pest is currently being pursued in the United States (Ledbetter and Shonnard, 1991), France (Crossa-Raynaud and Audergon, 1987; Stalin et al., 1998), and in Spain (Alcañiz et al., 1996; Marull and Pinochet, 1991; Pinochet, 1997). Resistance has been difficult to find (Ledbetter, 1994) and to transmit from wild Prunus into commercial rootstocks. Recent findings also indicate the existence of differences in pathogenicity among populations of $P$. vulnus (Pinochet et al., 1993b; 1994), a consideration that further complicates the evaluation of plant material in the search for resistance and tolerance.

The purpose of this study was to evaluate the susceptibility of 29 Prunus rootstocks (mainly peach and plum), some of which have been reported to be resistant (low reproduction) or suspected to be tolerant (nematode reproduces well but plant growth is minimally affected) to this nematode in the United States, France, Italy, and Spain to mixtures of several isolates of $P$. vulnus. A second objective was to determine the comparative reproduction of seven $P$. vulnus populations on five supposedly resistant Prunus rootstocks. Nearly all the tested rootstocks have incorporated rootknot nematode resistance (Esmenjaud et al., 1997; Fernández et al., 1994; Pinochet et al., 1999); many are new cultivar releases or materials in advanced stages of selection.

\section{Materials and Methods}

Plantmaterial. Seeds, herbaceous and hardwood cuttings, and micropropagated material were supplied by public research institutes and private sources in Spain, France, and the United States (Table 1). Seeds of the peach rootstocks 'Rutgers Red Leaf', 'Montclar', and 'Flordaguard' were treated with a 5\% solution of copper oxychloride for $24 \mathrm{~h}$, rinsed with running water, covered with moist paper towel, stratified in perlite trays (Europerlite ${ }^{\circledR}$; Dicalite Española, S.A., Barcelona, Spain), and kept in a cool chamber at $4{ }^{\circ} \mathrm{C}$ for $45 \mathrm{~d}$. The seeds were then moved to an ambient temperature greenhouse $\left(16\right.$ to $\left.30^{\circ} \mathrm{C}\right)$ to induce germination.

The plums 'Bruce' $(P$. salicina $\times P$. angustifolia Marsh) and 'Orotava' ( $P$. salicina) were propagated from herbaceous cuttings. 'Bruce', 'Orotava', and 'Montizo' ( $P$. insititia) plum were obtained from the Departamento de Fruticultura del Servicio de Investigación Agraria de la Diputación General de Aragón, Zaragoza. 'Adarcias' (P. dulcis $\times$ P. persica) was supplied by the Estación Experimental Aula Dei, Consejo Superior de Investigaciones Científicas, Zaragoza. Hardwood cuttings of 'Montizo' and 'Adarcias' were treated for $10 \mathrm{~s}$ with a $50 \%$ alcohol solution that contained $2000 \mathrm{mg} \cdot \mathrm{L}^{-1}$ of indole butyric acid. Cuttings then were planted in small pots (200 $\mathrm{cm}^{3}$ ) containing a pasteurized 3 sand : 1 peat mixture (v:v). Peach 'Cadaman' P. persica $\mathrm{X}$ $P$. davidiana (Carr.) Franch., plum 'Adara' $(P$. cerasifera), 'Torinel', 'Julior' ( $P$. insititia $\times P$. 
Table 1. Prunus rootstocks and selections evaluated against Pratylenchus vulnus in Spain.

\begin{tabular}{|c|c|c|}
\hline Species & Rootstock/selection & Source $^{\mathrm{z}}$ \\
\hline & Plum & \\
\hline P. salicina $\times$ P. angustifolia & Bruce & Texas A\&M \\
\hline P. besseyi $\times P$. salicina & Deep Purple & WSU \\
\hline$P$. salicina $\times P$. munsoniana & Redglow & Univ. of Minnesota \\
\hline \multirow[t]{2}{*}{ P. salicina } & Orotava & Unknown, Canary Is., Spain \\
\hline & Laroda F1OP & ISF Rome, Italy \\
\hline \multirow[t]{2}{*}{ P. insititia } & Montizo & SIA-DGA, Spain \\
\hline & AC-952 & AC, Spain \\
\hline \multirow[t]{3}{*}{ P. domestica } & Torinel & INRA, France \\
\hline & Tetra & ISF Rome, Italy \\
\hline & Penta & ISF Rome, Italy \\
\hline \multirow{2}{*}{$P$. insititia $\times P$. domestica } & Julior & INRA, France \\
\hline & AC-959 & AC, Spain \\
\hline \multicolumn{2}{|l|}{$(P$. cerasifera $\times$ P. salicina $) \times$} & INRA, France \\
\hline$P$. cerasifera $\times P$. munsoniana & Marianna 4001 & Univ. of California \\
\hline P. cerasifera & $\begin{array}{l}\text { Myrocal } \\
\text { Adara }\end{array}$ & $\begin{array}{l}\text { INRA, France } \\
\text { CSIC, Spain }\end{array}$ \\
\hline$P$. cerasifera $\times(P$. dulcis $\times P$. persica $)$ & $\begin{array}{l}\text { Peach-plum } \\
\text { AC-960 }\end{array}$ & AC, Spain \\
\hline P. persica & $\begin{array}{c}\text { Peach } \\
\text { Montclar } \\
\text { Rutgers Red Leaf }\end{array}$ & $\begin{array}{l}\text { INRA, France } \\
\text { Rutgers Univ. }\end{array}$ \\
\hline \multirow{2}{*}{$\begin{array}{l}P \text {. persica } \times P \text {. davidiana } \\
P \text {. persica }\end{array}$} & Cadaman & INRA, France \\
\hline & Flordaguard & Univ. of Florida. \\
\hline \multirow{6}{*}{ P. dulcis $\times$ P. persica } & $\begin{array}{l}\text { Peach-almond } \\
\text { Felinem }\end{array}$ & SIA-DGA, Spain \\
\hline & AC-9000 & $\begin{array}{l}\text { AC, Spain } \\
\text { AC }\end{array}$ \\
\hline & AC-9501 & AC, Spain \\
\hline & AC-9502 & AC, Spain \\
\hline & Adarcias & CSIC, Spain \\
\hline & Mayor & CIDA, Spain \\
\hline P. persica $\times$ P. dulcis & Sirio & Univ. of Pisa, Italy \\
\hline P. cerasus & $\begin{array}{l}\text { Cherry } \\
\text { CAB-6P }\end{array}$ & Univ. of Bologna, Italy \\
\hline
\end{tabular}

${ }^{2}$ Texas A\&M Univ., College Station; WSU = Washington State Univ., Prosser; Univ. of Minnesota, St. Paul; ISF = Istituto Sperimentale per la Fruticoltura di Roma; SIA-DGA = Servicio de Investigación Agraria de la Diputación General de Aragón, Zaragoza; AC = Agromillora Catalana, S.A., Barcelona; INRA = Institut National de la Recherche Agronomique, Bordeaux; Univ. of California, Davis; CSIC = Consejo Superior de Investigaciones Científicas, Zaragoza; Rutgers Univ., New Brunswick; N.J.; Univ. of Florida, Gainesville; CIDA = Centro de Investigación y Desarrollo Agrario, Murcia; Univ. of Pisa; Univ of Bologna.

domestica $)$, 'Ishtara' $[(P$. cerasifera $\times P$. salicina $) \times(P$. cerasifera $\times$ P. persica $)]$, 'Deep Purple' ( $P$. besseyi Bailey $\times$ P. salicina $)$, 'Redglow', Laroda F1OP ( $P$. salicina), AC952 ( $P$. insititia), AC-959 ( $P$. insititia $\times P$. domestica), AC-960 $[P$. cerasifera $\times(P$. dulcis $x$ P.persica)], 'Marianna 4001', and 'Myrocal' $(P$. cerasifera), the peach-almond hybrids $(P$. dulcis $\times$ P. persica) 'Felinem', AC-9000, AC9501, AC-9502, and 'Mayor', and the cherry 'CAB 6P' (P. cerasus L.) were micropropagated at Agromillora Catalana S.A., Sant Sadurní d' Anoia, Barcelona, Spain. Plantlets were transferred from agar (Murashige and Skoog, 1962) to 50-mL minipot trays containing a moor peat and clay substrate (Stender Bassis Substrate 3, Blumenerdenwerke Stender, Schermbeck, Germany) and acclimatized in a high humidity chamber for 24-30 d. The rootstocks 'Tetra' (P. domestica), 'Penta' ( $P$. domestica), and 'Sirio' ( $P$. persica $\times P$. dulcis), were received from Vivai Battistini, Diegaro di Cesena, Italy.

Inoculum source and preparation. A total of $11 P$. vulnus populations originating from different geographic locations and hosts were obtained from several sources (Table 2). The
$<3 \%$ organic matter content and a cation exchange capacity (CEC) of $<120 \mathrm{meq} \cdot \mathrm{kg}^{-1}$.

Plants with uniform growth of $\approx 20 \mathrm{~cm}$ height (10-15 leaves) were inoculated with a suspension of 900 nematodes per plant at 6 weeks after transplanting. In order to assure a desired pathogenic diversity for testing plant material (Pinochet et al., 1993b), inoculum consisted of a mixture of equal proportions of nine $P$. vulnus populations. The populations used in the first (1996) and second (1997) trial were: Pv RO-S, Pv PL-S, Pv WA-A, Pv OL-I, Pv PL-F, Pv WA-US, Pv AP-US, Pv AP-S, and Pv ST-J (Table 2). In the third trial (1998), nine $P$. vulnus isolates were also used, but two isolates used in the previous trials were not available and were replaced by two new $P$. vulnus isolates resulting in the following inoculum mixture: Pv RO-S, Pv PL-S, Pv WAA, Pv OL-I, Pv PL-F, Pv AT-F, Pv PE-US, Pv AP-US, and Pv ST-J (Table 2).

Inoculated plants were placed in a sand bed to avoid fluctuations in temperature and humidity. Each rootstock was replicated seven or eight times in a completely randomized design. Plants were watered as needed and fertilized weekly with half-strength Hoagland's (Hoagland and Arnon, 1950) nutrient solution. The rootstocks 'Ishtara' or 'Cadaman' were used as susceptible reference rootstocks, whereas 'Torinel' was included as the resistant reference rootstock in each trial. Ambient temperature in the greenhouse fluctuated between 12 and $35^{\circ} \mathrm{C}$.

Experiment number four (1999) was established to confirm results of rootstocks that had shown a resistant response or a low host susceptibility (nonhost or poor host) in the three previous host susceptibility trials. These rootstocks were 'Bruce', 'Deep Purple', 'Torinel', and 'Redglow' plums, and the peach-almond hybrid 'Felinem'. In this experiment, seven $P$. vulnus populations were used, but in contrast with previous trials, each rootstock was challenged with individual populations. These populations were Pv ROS, Pv PL-S, Pv WA-A, Pv OL-I, Pv AT-F, Pv PE-US, and Pv ST-J. Rootstocks were inoculated with a suspension of 400 nematodes per plant 7 weeks after transplanting. Nematode reproduction was assessed $150 \mathrm{~d}$ after inoculation on a per gram root basis, regarded as the most reliable criteria for measuring host suitability or susceptibility (Culver et al., 1989). Greenhouse and experimental conditions were the same as those described for the host susceptibility trials.

Final nematode populations in roots and numbers of nematodes per gram of root were assessed at the end of each experiment. Nematodes were extracted by cutting the whole root system into $1-\mathrm{cm}-$ long pieces and macerating them with water in a commercial blender at $14,500 g_{\mathrm{n}}$ for a total of $30 \mathrm{~s}$ given as $10-\mathrm{s}$ blendings. The nematode suspension was then concentrated through $150-, 74-$, and $20-\mu \mathrm{m}-$ pore sieves $(100,200$, and 600 mesh, respectively). Root tissue and debris collected on the $150-\mu \mathrm{m}$-pore sieve were discarded. Nematodes were extracted from the remaining sample by sugar flotation (Jenkins, 1964). 
Data on nematode reproduction were analyzed by a one-way analysis of variance. Data were $\log _{10}$ transformed $(x+1)$ for analyses. When $\mathrm{F}$ values were significant, differences between means were compared using Fisher's LSD test $(P \leq 0.05)$. The reproduction factor: $\mathrm{Rf}=$ final population density $(\mathrm{Pf})$ of all the life stages divided by the initial population density (Pi) was calculated as a measure of host susceptibility among the different treatments. Host rating used in relation to $\mathrm{Rf}$ values were the following: $\mathrm{Rf}=0$ (nonhost); $\mathrm{Rf}=0.01-1.99$ (poor host); $\mathrm{Rf}=2.0+$ (suitable host)

\section{Results}

Host susceptibility experiments. In the first trial (1996), 'Felinem' showed the lowest final nematode population, followed by 'Torinel', 'Bruce', and 'Deep Purple', although 'Deep Purple' did not differ from 'Julior'. The remaining rootstocks, 'Orotava', 'Myrocal', 'Montclar', 'Montizo', and 'Ishtara' presented high levels of population buildup in the roots (Table 3). 'Felinem', and 'Torinel' showed a significantly lower number of nematodes per gram of roots, 128 and 225, respectively. 'Bruce' did not differ from 'Torinel' or 'Deep Purple'. Significantly higher levels of high nematode parasitism were found among the remaining rootstocks. Nematode reproduction factor was low for 'Felinem' (Rf value of 1.47) but highest in 'Ishtara' (Rf value of 57.11).

In the second trial (1997), 'Torinel' showed the lowest final nematode population, followed by 'Penta', 'Tetra', 'CAB-6P', and 'Laroda F1OP', although these last three rootstocks did not differ from the rest of the tested materials with the exception of 'Mayor', which had the highest nematode reproduction. 'Torinel' also had the lowest numbers of nematodes per gram of root, followed by 'Tetra', 'Adara', and 'Cadaman'. 'Penta', 'CAB-6P', 'LarodaF1OP', 'Sirio', and 'Rutgers Red Leaf' showed a significantly higher level of parasitism but did not differ from 'Cadaman'. The peach-almond hybrid 'Mayor' had the highest nematode density of 10,160 nematodes per gram of roots. Reproduction factor was low for 'Torinel' $(\mathrm{Rf}=1.42)$ and highest in 'Mayor' $(\mathrm{Rf}=33.85)$.

In the third trial (1998), the final nematode population in roots was lowest in 'Redglow' and 'Torinel', although the latter did not differ from AC-959, followed by 'Marianna 4001' and AC-9000. 'Bruce' was similar to AC-9000 but differed from the remaining rootstocks, which ranged from 11,270 nematodes in 'Adarcias' to 93,260 in AC-952. 'Redglow', 'Torinel', and AC-959 had the lowest numbers of nematodes per $\mathrm{g}$ root, followed by 'Marianna 4001', although 'Marianna 4001' did not differ from AC-959 or 'Bruce'. The remaining rootstocks showed varying levels of high nematode densities in the roots with 'Ishtara' (4960) and AC-952 (6230) having the highest. Reproduction factors were low in 'Redglow' (0.23), 'Torinel' (0.85), AC-959 (1.71) and 'Marianna 4001' (2.68). In contrast, AC-952 had the highest Rf (103.62)
Table 2. Origin of eleven populations of Pratylenchus vulnus used in this study.

\begin{tabular}{|c|c|c|c|}
\hline Populations & Geographic origin & Host & Source $^{2}$ \\
\hline$\overline{\text { PvRO-S }}$ & Barcelona, Spain & Rose (Rosa multiflora Thunb.) & $\overline{\text { IRTA }}$ \\
\hline PvPL-S & Alicante, Spain & Plum (Prunus domestica) & IRTA \\
\hline PvAP-S & Girona, Spain & Apple (Malus $\times$ domestica) & IRTA \\
\hline PvAT-F & Antibes, France & Apricot (Prunus armeniaca L.) & INRA \\
\hline PvPL-F & Dorogne, France & Plum (Prunus domestica) & INRA \\
\hline PvWA-A & Córdoba, Argentina & Walnut (Juglans regia $\mathrm{L})$. & UNC \\
\hline PvOL-I & Taranto, Italy & Olive (Olea europea L.) & INA \\
\hline PvPE-U & Georgia, USA & Peach (Prunus persica) & USDA \\
\hline PvWA-US & California, USA & Walnut (Juglans regia) & UCR \\
\hline PvAP-US & Idaho, USA & Apple (Malus $\times$ domestica) & UI \\
\hline PvST-J & Kyushu, Japan & Strawberry (Fragaria sp.) & UCR \\
\hline
\end{tabular}

${ }^{2}$ IRTA = Institut de Recerca i Tecnologia Agroalimentàries, Barcelona, Spain; INRA = Institut National de la Recherche Agronomique, Antibes, France; INA = Instituto di Nematologia Agraria, Bari, Italy; UNC = Universidad Nacional de Córdoba, Córdoba, Argentina; U.S. Department of Agriculture, Byron, Ga.; UCR = Univ. of California, Riverside; UI = Univ. of Idaho, Parma.

Table 3. Reproduction of Pratylenchus vulnus on 29 Prunus rootstocks $120 \mathrm{~d}$ after inoculation with 900 nematodes per plant in three greenhouse trials.

\begin{tabular}{|c|c|c|c|}
\hline Rootstock & $\begin{array}{c}\text { Final nematode } \\
\text { population in roots }\end{array}$ & $\begin{array}{l}\text { Nematodes } \\
\text { per g of root }\end{array}$ & $\operatorname{Rf}^{\mathrm{y}}$ \\
\hline \multicolumn{4}{|c|}{ Trial 1 (1996) } \\
\hline Felinem & $1,330 a^{x}$ & $128 \mathrm{a}$ & 1.47 \\
\hline Torinel $^{\mathrm{TM}}$ & $3,360 \mathrm{~b}$ & $225 \mathrm{ab}$ & 3.73 \\
\hline Bruce & $3,600 \mathrm{~b}$ & 810 bc & 4.00 \\
\hline Deep Purple & $3,900 \mathrm{bc}$ & $1,100 \mathrm{c}$ & 4.33 \\
\hline Julior & $7,590 \mathrm{~cd}$ & $1,400 \mathrm{~d}$ & 8.43 \\
\hline Orotava & $12,570 \mathrm{de}$ & $2,010 \mathrm{de}$ & 13.96 \\
\hline Myrocal & 26,860 ef & $2,680 \mathrm{e}$ & 29.94 \\
\hline Montclar & $29,700 \mathrm{f}$ & $2,940 \mathrm{e}$ & 33.00 \\
\hline Montizo & $38,850 \mathrm{f}$ & $2,340 \mathrm{e}$ & 43.17 \\
\hline Ishtara & $51,400 \mathrm{f}$ & $4,290 \mathrm{e}$ & 57.11 \\
\hline \multicolumn{4}{|c|}{ Trial 2 (1997) } \\
\hline Torinel & $1,280 a^{x}$ & $105 \mathrm{a}$ & 1.42 \\
\hline Penta & $6,210 \mathrm{~b}$ & $1,330 \mathrm{c}$ & 6.90 \\
\hline Tetra & $10,740 \mathrm{bc}$ & $500 \mathrm{~b}$ & 11.93 \\
\hline CAB-6P & $11,780 \mathrm{bc}$ & $2,990 \mathrm{c}$ & 13.08 \\
\hline Laroda F1OP & $12,030 \mathrm{bc}$ & $1,420 \mathrm{c}$ & 13.36 \\
\hline Sirio & $16,250 \mathrm{c}$ & $1,060 \mathrm{c}$ & 18.05 \\
\hline Adara & $17,240 \mathrm{c}$ & $650 \mathrm{~b}$ & 19.15 \\
\hline Cadaman & $19,510 \mathrm{c}$ & $940 \mathrm{bc}$ & 21.67 \\
\hline Rutgers Red Leaf & $19,630 \mathrm{c}$ & $1,770 \mathrm{c}$ & 21.80 \\
\hline Mayor & $30,470 \mathrm{~d}$ & $10,160 \mathrm{~d}$ & 33.85 \\
\hline \multicolumn{4}{|c|}{ Trial 3 (1998) } \\
\hline Redglow & $211 a^{x}$ & $32 \mathrm{a}$ & 0.23 \\
\hline Torinel & $770 \mathrm{ab}$ & $140 \mathrm{a}$ & 0.85 \\
\hline AC-959 & $1,540 \mathrm{bc}$ & $190 \mathrm{ab}$ & 1.71 \\
\hline Marianna 4001 & $2,420 \mathrm{~cd}$ & $360 \mathrm{bc}$ & 2.68 \\
\hline AC-9000 & $4,350 \mathrm{de}$ & $2,070 \mathrm{~d}$ & 4.83 \\
\hline Bruce & 5,050 ef & $1,120 \mathrm{~cd}$ & 5.61 \\
\hline Adarcias & $11,270 \mathrm{ghi}$ & $1,900 \mathrm{~d}$ & 12.52 \\
\hline Deep Purple & $18,180 \mathrm{ijk}$ & 3,710 def & 20.20 \\
\hline AC-9501 & $23,310 \mathrm{jkl}$ & $2,960 \mathrm{def}$ & 25.90 \\
\hline AC-9502 & $31,620 \mathrm{jkl}$ & 2,714 def & 35.13 \\
\hline Flordaguard & $38,300 \mathrm{~lm}$ & $2,080 \mathrm{de}$ & 42.55 \\
\hline Felinem & $47,200 \mathrm{~lm}$ & $2,210 \mathrm{de}$ & 52.44 \\
\hline Ishtara & $53,490 \mathrm{~lm}$ & 4,960 ef & 59.43 \\
\hline AC-960 & $54,170 \mathrm{~lm}$ & $2,820 \mathrm{de}$ & 60.18 \\
\hline AC-952 & $93,260 \mathrm{~m}$ & $6,230 \mathrm{f}$ & 103.62 \\
\hline
\end{tabular}

"Pratylenchus vulnus populations used in trial 1 (1996) and 2 (1997): $\mathrm{Pv}$ RO-S, Pv PL-S, Pv WA-A, Pv OL-I, Pv PL-F, Pv WA-US, Pv AP-US, Pv ST-J, and Pv AP-S. P. vulnus populations used in trial 3 (1998): Pv RO-S, Pv PL-S, Pv WA-A, Pv OL-I, Pv PL-FR, Pv AT-FR, Pv PE-US, Pv AP-US, and PV ST-J.

${ }^{y} \mathrm{Rf}$ : Reproductive factor $(\mathrm{Pf} / \mathrm{Pi})$ where $\mathrm{Pi}=$ initial population density was equivalent to 20 nematodes per $100 \mathrm{~cm}^{3}$ of soil.

'Data are means of seven or eight replications. Actual data are presented, but data were transformed to $\log _{10}(x+1)$ for analysis. Mean separation within columns and trials by Fisher's LSD test $(P \leq 0.05)$. 
Table 4. Reproduction of seven populations of Pratylenchus vulnus on five Prunus rootstocks $150 \mathrm{~d}$ after inoculation with 400 nematodes per plant.

\begin{tabular}{|c|c|c|c|c|c|}
\hline \multirow[b]{2}{*}{ Population } & \multicolumn{5}{|c|}{ Final nematode population (No. per g of root) } \\
\hline & Torinel & Deep Purple & Bruce & Felinem & Redglow \\
\hline Pv ST-J & $30 \mathrm{a} \mathrm{A}^{\mathrm{z}}$ & $110 \mathrm{a} B$ & 5 a $\mathrm{A}$ & $180 \mathrm{ab} B$ & 25 a $\mathrm{A}$ \\
\hline Pv PE-U & 195 b A & 2480 с C & 890 с B & 4700 c C & 26 a $\mathrm{A}$ \\
\hline Pv WA-A & $370 \mathrm{~b} \mathrm{~B}$ & $3440 \mathrm{~d} \mathrm{C}$ & 1180 c C & $260 \mathrm{ab} B$ & 18 a $\mathrm{A}$ \\
\hline Pv RO-S & 590 b B & 1610 c B & 1100 c B & 100 a $\mathrm{A}$ & 9 a $\mathrm{A}$ \\
\hline Pv PL-S & $400 \mathrm{~b} \mathrm{~B}$ & 940 bc BC & 1400 c C & $460 \mathrm{~b} \mathrm{~B}$ & 22 a $\mathrm{A}$ \\
\hline Pv AT-F & $650 \mathrm{~b} \mathrm{~B}$ & 2510 c C & $120 \mathrm{~b} \mathrm{~A}$ & 30 a A & --- \\
\hline Pv OL-I & 390 b B & $580 \mathrm{~b} \mathrm{~B}$ & 0 a A & $700 \mathrm{~b} \mathrm{~B}$ & 17 a $\mathrm{AB}$ \\
\hline
\end{tabular}

${ }^{2}$ Data are means for eight replications. Actual data are presented but data were transformed to $\log _{10}$ $(\mathrm{x}+1)$ for analysis. Mean separation within rows (upper case letters) and columns (lower case letters) by Fisher's LSD test $(P \leq 0.05)$.

When individual isolates were inoculated on the five rootstocks that had exhibited a low host suitability or resistance in previous trials ('Torinel', 'Deep Purple', 'Bruce', 'Felinem', and 'Redglow'), the Japanese population ( $\mathrm{Pv}$ ST-J) reproduced significantly less than did other populations in 'Torinel' (Table 4). 'Deep Purple' showed different levels of parasitism ranging from a low of 110 nematodes per $\mathrm{g}$ with Pv ST-J, to a very high level of 3440 nematodes per $g$ root when inoculated with the Pv WA-A from Argentina. 'Bruce' was a poor and nonhost to populations Pv ST-J and Pv OL-I, respectively. The French isolate Pv AT$F$ had lower reproduction on 'Bruce' than did the other nematode isolates. On 'Felinem', Pv AT-F and Pv RO-S reproduced less than did Pv PL-S, Pv OL-I, and Pv PE-U, but did not differ from Pv ST-J or Pv WA-A. The U.S. population Pv PE-U exhibited the highest number of nematodes per $g$ root (4700). Parasitism in 'Redglow' was very low for all $P$. vulnus populations. No differences among populations were detected. Although significant differences in reproduction on the various genotypes were evidenced for each $P$. vulnus population, no relationship was found for a given population in its capacity to multiply evenly on the five rootstocks.

\section{Discussion}

Nearly all the evaluated rootstocks were suitable hosts for $P$. vulnus as indicated by high population densities in the roots. However, a few cultivars proved to be poor hosts with final population levels lower or slightly higher than the initial inoculation levels. 'Torinel', AC-959, 'Marianna 4001', and 'Redglow' appear to be the the most interesting materials tested so far, although AC-959 and 'Marianna 4001' will require repeated evaluation to verify the results obtained under greenhouse conditions. As difficult as it is to accurately determine plant host resistance to root-lesion nematode, the number of nematodes per gram of root continues to be regarded as the most reliable parameter in measuring host suitability, and probable susceptibility.

'Redglow' ( $P$. salicina 'Burbank' $\mathrm{x} P$. munsoniana 'Jewell') is an American plum selected in 1919 at the Univ. of Minnesota (American Society for Horticultural Science, 1997). This cultivar is dwarf, hardy, and productive, but of little or no commercial value. However, it was the most promising rootstock from the point of view of nematode resistance, and perhaps the best source of broad resistance to $P$. vulnus so far detected in a commercial Prunus rootstock. 'Redglow' supported the lowest numbers of nematodes in the roots and was resistant to all $P$. vulnus populations tested. The few specimens extracted from the roots were always adult forms (no larvae or eggs were detected), suggesting that they may have been remnants of the original inoculum that penetrated the roots but were incapable of multiplying in the root tissue. 'Redglow' is resistant to this nematode in the United States (Ledbetter, pers. comm.).

The agronomic potential of 'Redglow' as a plum or peach rootstock appears to be limited. Little is known about its response to other soil-borne pathogens and abiotic stress factors. The main problem with 'Redglow' is that it is difficult to propagate by hardwood or herbaceous cuttings; with some success, around $25 \%$ to $30 \%$ survival (unpublished) has been observed with in vitro techniques.

'Felimen', previously known as $\mathrm{G} \times \mathrm{N}$ No. 22, is a red-leafed peach-almond hybrid selected recently in Spain. It was resistant to $P$. vulnus in previous evaluations (Alcañiz et al., 1996) and in our 1996 trial. However, results obtained in 1998 were disappointing, with 2210 nematodes per g root, a density typical of a highly susceptible host. Individual population inoculations revealed that population $\mathrm{PV}$ PE-U readily multiplied on 'Felinem' (Table 4), whereas most of the $P$. vulnus populations were unsuitable or poor hosts for the nematode. Population Pv PE-U, isolated from peach in Georgia, had not been used in previous trials, which would explain the discrepant results between trials. This case also indicates the pathogenic diversity of this species on a given rootstock. In addition, little is known as to how the resistance trait of $P$. vulnus is transmitted.

Our results suggest that pooling genes from several sources with partial resistance to one or several $P$. vulnus populations, such as those found in 'Bruce', 'Deep Purple', 'Torinel' and 'Felinem', is a sound approach for obtaining a broader spectrum of resistance. However, this task has proved to be difficult because of the lack of genetic compatibility of the Prunus species involved (Okie and Weinberger, 1996). In Spring 1999 crosses between several of these parents that have partial resistance to several populations were carried out. A total of 1220 pollinations of 'Deep Purple' by 'Felinem' produced three hybrid seedlings $(P$. salicina $\times P$. besseyi $) \times$ $(P$. dulcis $\times P$. persica). Several hundred additional pollinations made between 'Redglow' x 'Felinem', 'Deep Purple' $x$ 'Redglow', and 'Bruce' $x$ 'Felinem', produced two more seeds, but the seedlings died following germination, underscoring the difficulty in achieving a descendant with these potential sources of resistance.

From the agronomic standpoint, the most interesting rootstock tested was 'Torinel'. It is a commercial European plum $(P$. domestica), released in France in 1989 by INRACTIFL as a plum rootstock for apricot cultivars. 'Torinel' consistently proved to be a very poor host in mixtures and when challenged individually to most populations of $P$. vulnus. Testing carried out by Alcañiz et al. (1996) confirmed its low host suitability. The second most interesting rootstock was the experimental hybrid plum selection AC-959 (P. domestica $\times$ P. insititia) which proved to be a poor host for $P$. vulnus, although it was evaluated in only one experiment (Table 3 ). Both 'Torinel' and AC-959 adapt well to heavy and calcareous soils, and are also immune to root-knot nematodes (Pinochet et al., 1996b, and unpublished).

Breeding for resistance against $P$. vulnus has been a difficult task, and perhaps one of the most neglected areas of research in rootstock pathology. In general, little progress has been made in identifying sources of resistance in both wild and commercial Prunus and then, incorporating these sources into new rootstock material. Results have been limited, in relation to the efforts undertaken in the last 40 years, when compared, for example, with the success achieved with developing root-knot nematode resistance in peach and plum. Nevertheless, in spite of the few sources detected, our findings are encouraging, some in commercial plums, because we have a better understanding of the breeding strategies to be adopted in the future to allow for the pathogenic diversity of this pest.

The prohibition of methyl bromide fumigant in the year 2005 (Hansen, 1999) because of environmental concerns should accelerate research into developing rootstocks resistant to $P$. vulnus. Methyl bromide is commonly used in nursery operations worldwide and in many areas for orchard establishment, such as the Central Valley of California, where $P$. vulnus is widespread (McKenry, 1988). The banning of methyl bromide will have less effect on the control of root-knot nematodes, which can be effectively controlled by commercially available rootstocks (Nyczepir and Becker, 1998; Pinochet et al., 1999). In contrast, root-lesion nematode control will have to rely on less effective measures, such as fallow and the use of nonvolatile nematicides in granular formulations. At present, the use of tolerant rootstocks would seem to be the 
best management alternative, although it may be insufficient in the future, as replant activity takes place with less effective fumigants.

\section{Literature Cited}

Alcañiz, E., J. Pinochet, C. Fernández, D. Esmenjaud, and A. Felipe. 1996. Evaluation of Prunus rootstocks for root-lesion nematode resistance. HortScience 31:1013-1016.

The Brooks and Olmo register of fruit and nut varieties, 3rd ed. 1997. Amer. Soc. for Hort. Sci. Alexandria, Va.

Bertrand, P.F. 1989. Peach nematode management in the Southeastern United States, p. 751-757. In: N.F. Childers and W.B. Sherman (eds.) The peach. Horticultural Publications, Gainesville, Fla.

Crossa-Raynaud, P. and J.M. Audergon. 1987. Apricot rootstocks, p. 295-320. In: R.C. Rom and R.F. Carlson (eds.). Rootstocks for fruit crops. Wiley, New York.

Culver, D.J., D.W. Ramming, and M.V. McKenry. 1989. Procedures for field and greenhouse screening of Prunus genotypes for resistance and tolerance to root-lesion nematode. J. Amer. Soc. Hort. Sci. 114:30-35.

Esmenjaud, D., J.C. Minot, R. Voisin, J. Pinochet, M.H. Simard, and G. Salesses. 1997. Differential response to root-knot nematodes in Prunus species and correlative genetic implications. J. Nematol. 29:370-380.

Fernández, C., J. Pinochet, D. Esmenjaud, G Salesses, and A. Felipe. 1994. Resistance among new Prunus rootstocks and selections to rootknot nematodes from Spain and France. HortScience 29:1064-1067.

Fliegel, P. 1969. Population dynamics and pathogenicity of three species of Pratylenchus on peach. Phytopathology 59:120-124.

García de Otazo, L. 1992. La problemática de la replantación de frutales en las comarcas frutícolas de Lleida. Fruticultura Profesional 44:4-20.

Hansen, M. 1999. Methyl bromide gets reprieve for postharvest. Good Fruit Grower 50(1):22.

Hoagland, D. and D.I. Arnon. 1950. The water culture method for growing plants without soil. Calif. Agr. Exp. Sta. Circular No 347. Univ. of California, Berkeley.

Jaumot, M., Pinochet, J., and Fernández, C. 1997. Protein analysis of root-lesion nematodes using SDS-PAGE. Nematropica 27:33-39.

Jenkins, W.R., 1964. A rapid centrifugal flotation technique for separating nematodes from soil. Plant Dis. Rptr. 48:692.

Lamberti, F. 1981. Plant nematode problems in the Mediterranean region. Helm. Abs., Series B, Plant Nematology. Cmwlth. Inst. of Helm., St. Albans, Herts, England. 50:145-166.
Layne, R.E. 1987. Peach rootstocks, p. 385-216. In: R.C. Rom and R.F. Carlson (eds.). Rootstocks for fruit crops. Wiley, New York.

Ledbetter, C.L. 1994. Techniques for screening Prunus rootstocks for resistance to Pratylenchus vulnus, p. 34-36. In: A. P. Nyczepir, P.F. Bertrand and T.G. Beckman (eds.). Stone fruit tree decline, Sixth Wkshp. Proc. New insights and alternative management strategies. Fort Valley, Ga. 26-28 October 1992. USDA-ARS, ARS-122.

Ledbetter, C.L. and R. Shonnard. 1991. Evaluation of Prunus germplasm for resistance to lesion nematode (Pratylenchus vulnus). HortScience 26:709.

Marull J., and J. Pinochet. 1991. Host suitability of Prunus rootstocks to four Meloidogyne species and Pratylenchus vulnus in Spain. Nematropica 21:185-195.

McElroy, F.D. 1972. Nematodes of tree fruits and small fruits, p. 335-376. In: J.M. Webster (ed.). Econ. Nematol. Academic Press, London.

McKenry, M.V. 1988. Nematodes, p. 139-147. In: J.H. La Rue and R. Scott Johnson, (eds.). Peaches, Plums and Nectarines. Growing and Handling for Fresh Market. Coop. Extension, Univ. of Calif. Div. of Agr. and Natl. Res. Publ. 3331.

McKenry, M.V. 1989. Damage and development of several nematode species in a plum orchard. Appl. Agr. Res. 4:10-14.

Moody, E.H., B.F. Lownsbery, and J.M. Ahmed 1973. Culture of the root-lesion nematode Pratylenchus vulnus on carrot disks. J. Nematol. 5:225-226

Murashige, T. and F. Skoog. 1962. A revised media for rapid growth and bioassays with tabacco tissue culture. Physiol. Plant. 15:473-497.

Nyczepir, A.P., and O. Becker. 1998. Fruit and citrus trees, p. 637-684. In: Plant and nematode interactions. Agronomy monograph No. 36. Amer. Soc. of Agron., Crop Sci. Soc. of Amer., and Soil Sci. Soc. of Amer., Madison, Wis.

Nyczepir, A.P. and J.M. Halbrendt. 1993. Nematode pests of deciduous fruit and nut trees, $\mathrm{p}$. 381-425. In: K. Evans, D.L. Trudgill, and J.M. Webster (eds.). Plant parasitic nematodes in temperate agriculture. CAB Intl., Univ. Press, Cambridge, U.K.

Okie, W.R. 1987. Plum rootstocks. p. 321-360. In: R.C. Rom and R.F. Carlson, (eds). Rootstocks for fruit crops. Wiley, New York.

Okie, W.R., and Weinberger, J.H. 1996. Plum. p. 559-607. In: J. Janick and J.N. Moore (eds.). Fruit breeding. Vol. I. Tree and tropical fruits. Wiley, New York.

Pinochet, J. 1997. Breeding and selection for resistance to root-knot and lesion nematodes in Prunus rootstocks adapted to Mediterranean conditions. Phytoparasitica 25: 271-274.

Pinochet, J., M. Anglés, E. Dalmau, C. Fernández, and A. Felipe. 1996b. Prunus rootstock evaluation to root-knot and lesion nematodes in Spain. J. Nematol. 28:616-623.

Pinochet, J., C. Calvet, A. Hernández-Dorrego, A. Bonet, A. Felipe, and M. Moreno. 1999. Resistance of peach and plum rootstocks from Spain, France, and Italy to root-knot nematode Meloidogyne javanica. HortScience 34:12591262.

Pinochet, J., L. Cenis, C. Fernández, M. Doucet, and J. Marull. 1994. Reproductive fitness and random amplified polymorphic DNA variation among seven isolates of the root-lesion nematode Pratylenchus vulnus. J. Nematol. 26:271-277.

Pinochet, J., C. Fernández, E. Alcañiz, and A. Felipe. 1996a. Damage by a lesion nematode, Pratylenchus vulnus, to Prunus rootstocks. Plant Dis. 80:754-757.

Pinochet, J., C. Fernández, D. Esmenjaud, and M. Doucet. 1993b. Effects of six Pratylenchus vulnus isolates on the growth of peach-almond hybrid and apple rootstocks. J. Nematol. 25:843-848.

Pinochet, J., J. Marull, R. Rodríguez-Kábana, A. Felipe, and C. Fernández. 1993a. Pathogenicity of Pratylenchus vulnus on plum rootstocks. Fund. Appl. Nematol. 16:375-380.

Potter, J.W., V.A. Dirks, P. W. Johnson, T.H.A. Olthof, R.E.C. Layne, and M. M. McDonnell. 1984. Response of peach seedlings to infection by the root-lesion nematode Pratylenchus penetrans under controlled conditions. J. Nematol. 16:317-322.

Ramming, D.W. and V. Cociu. 1990. Peaches (Prunus). p. 175-132. In: J. N. Moore and J.R. Ballington Jr. (eds.). Genetic resources of temperate fruit and nut crops. Acta Hort. 290.

Ricciardi, P., A. Amici, and F. Lalatta. 1975. Ulteriori indagnini sul ruolo di Pratylenchus vulnus nel problema del reimpanto del pesco. Riv. Ortoflorofrut. It. 59:109-123.

Scotto La Massese, C. 1975. Tests d'hôtes de quelques porte-greffes et variétés fruitières à l'égard de Pratylenchus vulnus Allen et Jensen. Comptes Rendus Acad. Agr. de France 61:1088-1095.

Scotto La Massese, C. 1989. Les problèmes posés par les nématodes phytophages à l'amandier, p. 33-38. In: Options méditerranéennes. A.J. Felipe and R. Socías (eds). Séminaire du GREMPA sur les porte-greffes de l'amandier. Centre International de Haute Etudes Agronomiques Méditerranéennes, Zaragoza, España.

Stalin, N., G. Salesses, J. Pinochet, J.C. Minot, R. Voisin, and D. Esmenjaud. 1998. Comparative host suitability to Meloidogyne spp. and Pratylenchus vulnus in Myrobalan plum genotypes (Prunus cerasifera Ehr.). Plant Pathol. 47:211-215. 